\title{
Biological Studies on the Brown Dog Tick, Rhipicephalus sanguineus (Latreille)
}

\author{
Hanan S. M. Gabr ; Anar A. Bakr ${ }^{* *}$; Madiha M. Abdel Hamid ${ }^{\star *}$ and H., A. Senbill ${ }^{\text {** }}$ \\ Zoology Dept., Faculty of Agriculture, Cairo University. \\ **Applied Entomology Dept., Faculty of Agriculture, Alexandria University.
}

\begin{abstract}
Rhipicephalus sanguineus (Latreille, 1806) was reared under laboratory conditions of $27 \pm 3^{\circ} \mathrm{C}$ and $75 \pm 5 \% \mathrm{R}$. H., for three generations. The mean of life cycle duration was 41-73 days. The conversion efficiency index (CEI) was $0.3130 \pm 0.173$, the reproductive efficiency index (REI) was $33257.9 \pm 14895.7$ and the reproductive fitness index (RFI) was $9288.6 \pm 4481.9$. The males/ females ratio was 1.1:1. Females fed for $9 \pm 1.16$ days. Pre-oviposition and oviposition periods were $4.0 \pm 0.81$ and $7.5 \pm 1.72$ days respectively. Number of oviposted eggs per female averaged $4598 \pm 429.7$. A positive correlation was observed between the weight of engorged female and number of its deposited eggs $(r=0.76)$. However, the highest number of eggs was recorded on the $4^{\text {th }}$ day (1751 eggs/ female). Pre- hatching period was $15 \pm 1.87$ days and hatching rate was $92.4 \%$. Larvae and nymphs feeding periods were $4.5 \pm 1.16$ and $5.5 \pm 1.12$ days respectively,.
\end{abstract}

Key Words: Rhipicephalus sanguineus, Ixodidae, Life cycle, Biological parameter.

\section{INTRODUCTION}

Ticks (Acari: Ixodidae) are ectoparasites of great medical-veterinarian importance. As blood-feeding parasites, they cause direct damage to the infested animals due to their feeding behavior. They are implicated in the transmission of different pathogens (protozoa, bacteria, viruses and filarial nematodes), that cause tick-borne diseases affecting companion animals and humans (Azad and Beard, 1998; Jongejan \& Uilenberg, 2004 ; Parola et.al.,2005 and Dantas-torres,2007). Although Rhipicephalus sanguineus (Latreille, 1806) feeds primarily on dogs (Evans et,al., 2000), it can be found on a diverse range of wild and domestic animals, including numans (Estrada-peña and Jongejan, 1999; Dantastorres et.al., 2006). Accordingly, $R$ sanguineus is a competent vector of several pathogens causing diseases to dogs like Babesia vogeli, Ehrlichia canis and Hepatozoon canis. Also, ticks cause diseases to humans such Rickettsia conorii and $R$ rickettsii (Dantas-torres, 2008). Furthermore, it has been suggested that $R$ sanguineus could be involved in the transmission of several other pathogens such as, Anaplasma platys (Simpson et. al., 1991) and Leshmania infantum (Coutinho et. al., 2005). Although, a number of studies on the biology and ecology of $R$ sanguineus have been conducted in different parts of the world, there are still further investigations regarding the biology and ecology of this species. Therefore, life cycle of $R$ sanguineus under controlled laboratory conditions was conducted in this study.

\section{MATERIALS AND METHODS}

\section{Tick collection and identification:}

Adult ticks were manually collected from dogs at the Experimental Station Farm (Abies), Faculty of
Agriculture, Alexandria University. Ticks were placed individually into clean plastic vials and identified using the diagnostic keys and species description of walker et. al,. (2000).

\section{Colonization:}

$R$. sanguineus adults were colonized for three generations under laboratory conditions (darkened incubator at $27 \pm 3^{\circ} \mathrm{C}$ and $75 \pm 5 \% \mathrm{RH}$ ). Larvae, nymphs and adults were fed on domestic rabbits using capsule technique.

\section{Biological parameters assessed:}

The following biological parameters were recorded: engorged female weight; pre-oviposition period; oviposition period; pre-molting period; feeding periods of larvae, nymphs and adult females; egg mass weight; Conversion efficiency index (CEI), (weight of eggs/ weight of engorged female), Reproduction efficiency index (REI), (number of eggs/ weight of the engorged female), Reproductive fitness index (RFI), (number of hatching eggs/ weight of the engorged female) and egg incubation period.

\section{RESULTS AND DISCUSSION}

Biological parameters recorded for $R$ sanguineus fed on rabbits and maintained under laboratory conditions $\left(27 \pm 3^{\circ} \mathrm{C}\right.$ and $75 \pm 5 \%$ R.H.), for three laboratory generations, are shown in tables $(1 \& 2)$.

Adult stage: The female completed feeding in $9.0 \pm 1.16$ days ( $7-10$ days). The duration of the pre-oviposition period based on 15 females was $4.0 \pm 0.81$ days.

Oviposition period: The mean of oviposition period was 7.5 days (5-10), and that of eggs laied 


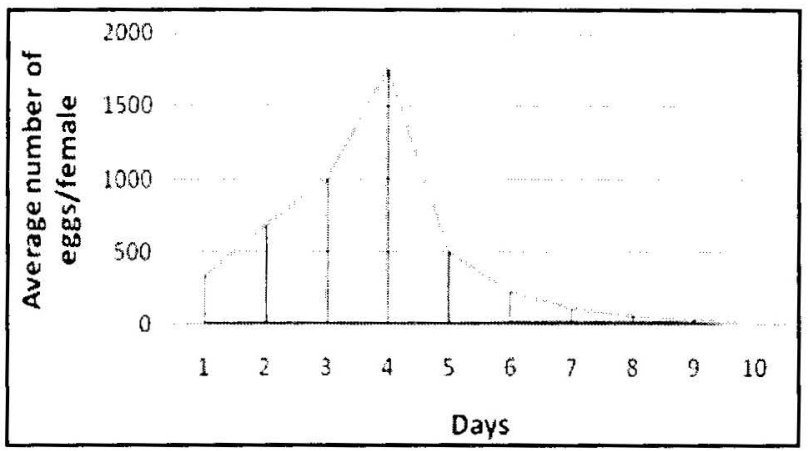

Fig. (1): Daily average oviposition of $R$ sanguineus maintained at $27^{\circ} \mathrm{C}$ and $75 \%$ R.H.

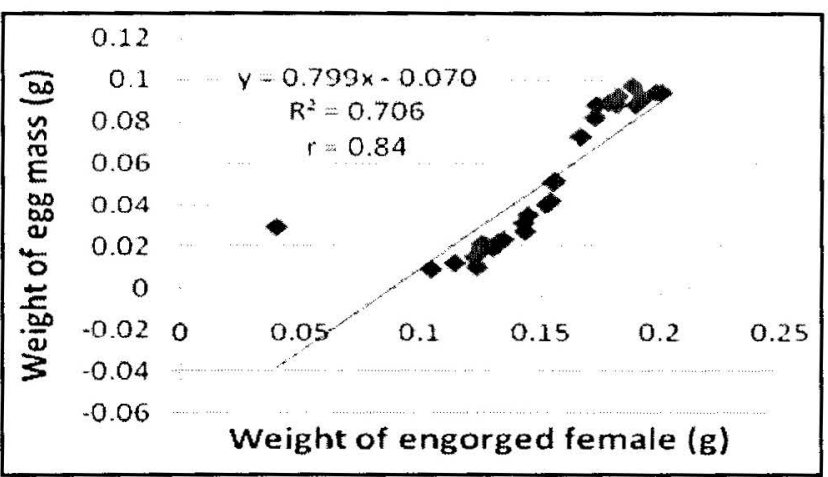

Fig. (2): Relationship between weight of eggs and weight of engorged females of $R$ sanguineus.

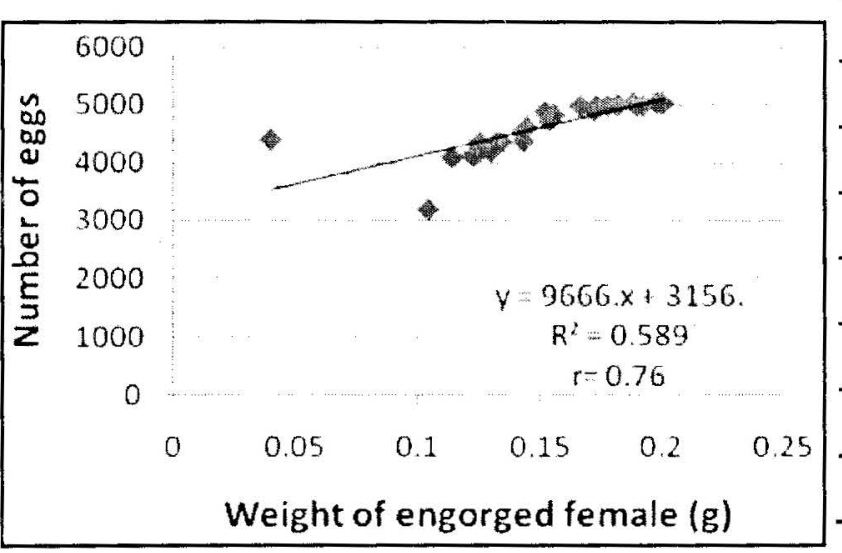

Fig. (3): Relationship between number of eggs and weight of engorged females of $R$ sanguineus.

per female was 4598 \pm 429.7. The mean daily oviposition rate is presented in (Fig.1). Oviposition proceeded rapidly reaching a peak on the $4^{\text {th }}$ day (1751 eggs/female), then declined thereafter. A positive correlation was found between the numbers of eggs laid and the weight of the engorged females $(r=0.76)$, (Fig. 2). A positive correlation was also found between the weight of the egg mass and the weight of the engorged females ( $r=0.84$ ), (Fig. 3).

Eggs: Mean of pre-hatching period (incubation) was $1.0 \pm 1.87$ days (10- 20 days).

Immature stages: The larval feeding period was $4.5 \pm 1.16$ days (3- 6 days). Mean of larval premoulting period was $11.6 \pm 1.41$ days (10- 14 days).
Table (1): Rhipicephalus sanguineus life cycle duration under laboratory conditions $\left(27 \pm 3^{\circ} \mathrm{C}\right.$ and $75 \pm 5 \%$ R.H.) fed on domestic rabbits

\begin{tabular}{lcc}
\hline \multirow{2}{*}{ Stage } & \multicolumn{2}{c}{ Duration (days) } \\
\cline { 2 - 3 } & range & mean $\pm \mathrm{SD}$. \\
\hline Pre-oviposition & $3-5$ & $4 \pm 0.81$ \\
\hline Oviposition & $5-10$ & $7.5 \pm 1.72$ \\
\hline Prehatching period & $10-20$ & $15 \pm 1.87$ \\
\hline Feeding larvae & $3-6$ & $4.5 \pm 1.16$ \\
\hline Pre-molting larvae & $10-14$ & $11.6 \pm 1.41$ \\
\hline Feeding nymphs & $4-7$ & $5.5 \pm 1.12$ \\
\hline Pre-molting nymphs & $9-16$ & $12.5 \pm 2.09$ \\
\hline Feeding female & $7-10$ & $9 \pm 1.16$ \\
\hline
\end{tabular}

Table (2): $R$. sanguineus females biological parameters

\begin{tabular}{lcc}
\hline \multicolumn{1}{c}{ Biological parameters } & Range & Mean \pm SD. \\
\hline $\begin{array}{l}\text { Weight of engorged females } \\
\text { (gm) }\end{array}$ & $0.0399-0.2001$ & $0.149 \pm 0.034$ \\
\hline Number of eggs laid/ female & $3200-5045$ & $4598 \pm 429.7$ \\
\hline Pre-oviposition period (days & $3-5$ & $4 \pm 0.81$ \\
\hline Oviposition period (days) & $5-10$ & $7.5 \pm 1.63$ \\
\hline Egg mass weight (gm) & $0.009-0.097$ & $0.049 \pm 0.032$ \\
\hline Egg hatch rate (\%) & $76.4-99.5$ & $92.4 \pm 7.389$ \\
\hline REI & $25137.4-34804.4$ & $33257.9 \pm 14895.7$ \\
\hline CEI & $0.081-0.515$ & $0.3130 \pm 0.173$ \\
\hline RFI & $43418.9-57356.5$ & $9288.6 \pm 4481.9$ \\
\hline REI: The index of Reproduction Efficiency. & \\
\hline CEI: The index of Conv &
\end{tabular}

CEI: The index of Conversion Efficiency.

RFI: The index of Reproduction Fitness.

Nymphs fed for $5.5 \pm 1.12$ days (4- 7 days), and its pre-moulting period was $12.5 \pm 2.09$ days $(9-16$ days).

The life cycle of $R$ sanguineus ranged between 41- 73 days under laboratory conditions (Table 1). Male/ female sex ratio was 1.1: 1 . The percentage of nymphs molted to males $(52.5 \%)$ was slightly higher than that molted to females $(47.5 \%)$.

$R$. sanguineus is a three-host tick that is, each active developmental stage (larva, nymph and adult) feeds only once. The life cycle was studied under laboratory conditions. The pre-oviposition period at $27^{\circ} \mathrm{C}$ was $4.0 \pm 0.81$ days, similar to the same periods $\left(3.8 \pm 1.1\right.$ days) at $26 \pm 1^{\circ} \mathrm{C}$ reportea by Dantas-Torres and Otranto (2011), as they indicated 
this period was longer in females exposed to low temperatures.

Oviposition reached its peak on the $4^{\text {th }}$ day, and sharply declined through the remaining oviposition period. Ixodid ticks are well-known for their prolific reproductive capacity. The number of eggs laid per female (averaged 4598) is higher than previously recorded by Dantas-Torres et. al., (2010). This may be due to the heavier engorgement weights of the females.

Significant linear relationship was found between the weight of engorged female of $R$ sanguineus and the number of egg masses laid (Figs. 2\&3), this was also reported by Dantas-Torres et. al., (2010a). Also, there was a positive relationship between CEI, REI and RFI and the weights of the females (Table 2). Dantas-Torres et. al., (2010a) reported similar correlations for $R$ sanguineus.

The mean prehatching period of $R$. sanguineus eggs at $27^{\circ} \mathrm{C}$ was $15 \pm 2.95$ which was longer than that reported by Dantas-Torres et. al., (2010b) at $26^{\circ} \mathrm{C}$ and was shorter than that reported by DantasTorres et,al. (2010a) for the same species and under the same temperature.

Males slightly out-numbered females (1.1:1) in our study. The sex ratio of $R$ sanguineus ticks collected from dogs is usually male-biased (DantasTorres et. al., 2009) due to the fact that males remain longer on the host than females.

In conclusion the of life cycle duration under laboratory conditions (41-73 days) lasts shorter than that reported for the same species (101.4 days) at $26^{\circ} \mathrm{C}$ (Dantas-Torres et,al., 2010a). In favorable conditions, the life cycle can be completed in 63-91 days (Goddard, 1987; Bechara et,al., 1995; Louly et,al., 2007). Under laboratory conditions, the biological parameters of $R$ sanguineus ticks vary greatly with temperature, relative humidity and host type (Bellato and Daemon, 1997).

\section{ACKNOWLEDGMENT}

The authors are grateful to Applied parasitic Acarine research laboratories, Faculty of Agriculture, Cairo University for facilities and support during this study.

\section{REFERENCES}

Azad, A.F. and Beard, C.B. 1998. Rickettsial pathogens and their arthropod vectors. Emerg. Infect. Dis. 4:179-186.

Bechara, G.H.; Szabo, M.P.J.; Ferreira, B.R. and
Garcia, M.V. 1995. Rhipicephalus sanguineus in Brazil: feeding and reproductive aspects under laboratorial conditions. Rev. Bras. Parasitol. Vet. 4:61-66.

Bellato, V. and Daemon, E. 1997. Efeitas de três temperatures sobre a fase não parasitária de Rhipicephalus sanguineus (Latreille, 1806) (Acari: Ixodidae), Rev. Bras. Parasitol. Vet. 6:21-27.

Coutinho, M.T.; Bueno, L.L.; Sterzik, A.; Fujiwara, R.T.; Botelho, J.R., De maria, M.; Genaro, O. and Linardi, P.M. 2005. Participation of Rhipicephalus sanguineus (Acari: Ixodidae) in the epidemiology of canine visceral leishmaniasis. Vet. Parasitol. 128:149-155.

Dantas-Torres, F. 2007. Rocky Mountain spotted fever. Lancet Infect. Dis. 7:724-732.

Dantas-Torres, F. 2008. The brown dog tick, Rhipicephalus sanguineus (Latreille, 1806) (Acari: Ixodidae): from taxonomy to control. Veterinary Parasitology. 152:173-185.

Dantas-Torres, F. and Otranto, D. 2011. Cold-stress response of engorged females of Rhipicephalus sanguineus. Exp. Appl. Acarol. 54:313-318.

Dantas-Torres, F., Figueredo, L.A. and BrandãoFilho, S.P. 2006. Rhipicephalus sanguineus (Acari: Ixodidae), the brown dog tick, Parasitizing humans in Brazil. Revista da sociedade Brasileira de Medicina Tropical, 39:64-67.

Dantas-Torres, F., Figueredo, L.A. and Otranto, D. $2010 \mathrm{~b}$. Seasonal variation in the effect of climate on the biology of Rhipicephalus sanguineus in southern Europe. Parasitology. 138:527-536.

Dantas-Torres, F.; Giannelli, A.; Figueredo, L.A. and Ornato, D. 2010a. Effects of prolonged exposure to low temperature on eggs of the brown dog tick, Rhipicephalus sanguineus (Latreille, 1806) (Acari:Ixodidae). Vet.Parasitol.171:327-330.

Dantas-Torres, F., Melo, M.F., Figueredo, L.A. and Brandão-Filho, S.P. 2009. Ectoparasite infestation on rural dogs in the municipality of sáo Vicente férrer, Pernambuco, Northeastern Brazil. Revista Brasileira de parasitologia veterinaria, 18:75-77.

Estrada-Peña, A. and Jongejan, F. 1999. Ticks feeding on humans: a review of records on human-biting ixodoidea with special reference to pathogen transmission. Exp. Appl. Acarol. 23:685-715.

Evans, D.E.; Martins, J.R. and Guglielmone, A. A. 2000. A review of the ticks (Acari: Ixodidae) of Brazil, their hosts and geographic distribition, the state of rio grande do sul, southern Brazil. Memórias do instituto oswaldo cruz. 95:453-470.

Goddard, J. 1987. Ticks of medical importance 
occurring in the western hemisphere. Texas: USA School of Aerospace medicine; $69 \mathrm{pp}$.

Jongejan, F. and Uilenberg, G. 2004. The global importance of ticks. Parasitology 129(Suppl):314.

Louly, C.C.B.; Fonseca, I.N.; Oliveira, V.F.; Linhares, G.F.C.; Menezes, L.B. and Borges, L.M.F. 2007. Seasonal dynamics of Rhipicephalus sanguineus (Acari: Ixodidae) in dogs from a police unit in Goiania, Goias, Brazil Cienc Rural. 37:464-469.

Parola, P.; Paddock, C.D. and Raoult, D. 2005. Tick- borne rickettsioses around the world: emerging diseases challenging old concepts. Clin. Microbiol. Rev. 18:719-756.

Simpson, R.M.; Gaunt, S.D.; Hair, J.A., Kocan, K.M.; Henk, W.G. and Casey, H.W. 1991. Evaluation of Rhipicephalus sanguineus as a potential biologic vector of Ehrlichia platys. Am. J. Vet. Res. 52:1537-1541.

Walker, J.B.; Keirans, J.E. and Horak, I.G. 2000. The genus Rhipicephalus (Acari: Ixodidae): A guide to the brown ticks of the world. Cambridge University press, Cambridge, UK., 643 pp. 